\title{
Sustainability Assessment of Technologies - An Integrative Approach
}

\author{
Armin Grunwald \\ Institute for Technology Assessment and Systems Analysis (ITAS), \\ Karlsruhe Institute of Technology (KIT), Karlsruhe
}

Germany

\section{Introduction}

The vision of sustainable development must by definition include both long-term considerations and the global dimension (World Commission on Environment and Development, 1987; Grunwald \& Kopfmüller, 2006). Pursuing this vision implies that societal processes and structures should be re-orientated so as to ensure that the needs of future generations are taken into account and to enable current generations in the southern and northern hemispheres to develop in a manner that observes the issues of equity and participation. Since a feature inherent in the Leitbild of sustainable development is consideration of strategies for shaping current and future society according to its normative content, guidance is necessary and the ultimate aim of sustainability analyses, reflections, deliberations, and assessments. The latter should result, in the last consequence, in knowledge for action, and this knowledge should motivate, empower, and support "real" action, decision-making, and planning (von Schomberg, 2002).

Technology is of major importance for sustainable development (see Sec. 2). On the one hand, technology determines to a large extent the demand for raw materials and energy, needs for transport and infrastructure, mass flows of materials, emissions as well as amount and composition of waste. Technology is, on the other side, also a key factor of the innovation system and influences prosperity, consumption patterns, lifestyles, social relations, and cultural developments. The development, production, use, and disposal of technical products and systems have impacts on all dimensions of sustainable development. Therefore, a sustainability assessment of the development, use, and disposal of technologies is required as an element of comprehensive sustainability strategies.

Technology Assessment (TA) has been developed since the 1960s as an approach first to explore possible unintended and negative side-effects of technology, to elaborate strategies for dealing with them and to provide policy advice (early warning, see Sec. 3). From the 1980s on the idea of shaping technology by early reflection on possible later impacts and consequences of technology was postulated (Bijker \& Law, 1994). The adaptation of this social constructivist programme to TA was done within the approach of Constructive Technology Assessment (CTA, cp. Rip et al., 1995). Parallel to this development in the field of TA the Leitbild of sustainable development became a major issue in public debate and scientific research. Against this background it is not surprising that TA took up the 
challenge to start thinking about shaping technology in accordance with sustainability principles (Weaver et al., 2000). Terms such as "transition management" (Kemp et al., 1998) and "reflexive governance" (Voss et al. 2006) were coined in order to demarcate the need for and approaches to embed sustainability assessments into the consideration of the governance of transformation processes toward sustainable development.

In the meantime TA has been used to assessing sustainability impacts of technology in a manifold of fields (see examples in Sec. 2). Main areas have been the fields of sustainable energy supply technologies, waste disposal, environmental technologies, mobility and transport, and also the exploration of sustainability potentials of new technologies such as nanotechnology and synthetic biology. However, these sustainability assessments differ considerably with respect to the understanding and operationalisation of the Leitbild of sustainable development. This situation makes comparisons between different assessments difficult if not impossible, and technology assessments with incompatible or diverging results may be criticized as being arbitrary. In order to overcome this situation, this chapter aims at introducing and proposing a general framework for sustainability assessments of technology.

There are strong needs to exploit and exhaust opportunities for shaping technology according to sustainability principles (see Sec. 2 and the examples given there) in the framework of sustainability strategies and policies because the production, use and disposal of technology is a highly influential power affecting many sustainability dimensions. Shaping technology with respect to sustainability needs preceding and early sustainability assessments of the technologies under consideration. The main objective of this chapter is to make use of the body of knowledge and experience from the field of technology assessment for sustainability assessments of technology by applying an integrative and transparent understanding of sustainable development. Meeting this objective requires, besides the knowledge about technology assessment (see Sec. 3), also a clear picture of how the Leitbild of sustainable development could be made operable. In this respect the integrative concept of sustainability (Kopfmüller et al., 2001) will be introduced (Sec. 4) and applied to the needs of sustainability assessment of technologies (Sec. 5). In addition, we will describe main methodical challenges of sustainability assessment of technology and give outlines how to meet them (Sec. 6).

\section{Shaping technology for sustainable development - the challenge}

Generally, a deep-ranging ambivalence of the roles of technology in regard to sustainable development can be observed. The relation between technology and sustainable development is usually discussed under contrary aspects: On the one hand, technology is regarded as a problem for sustainability and as cause of numerous problems of sustainability, but on the other hand, it is also and directly considered as a solution or at least one aspect of the solution of sustainability problems. This ambiguity is the reason for classifying the relation between technology and sustainability as ambivalent (Fleischer \& Grunwald, 2002).

On the one hand, the use of technologies in modern society has numerous impacts and consequences which conflict with sustainability requirements. This applies for ecological impacts, especially problems with emissions which are harmful for the environment or health and the rapid exploitation of renewable and non-renewable resources. Also in view 
of social aspects the technological progress causes sustainability problems, such as the consequence of the technical rationalization for the labour market. At the same time the distribution of both the possibilities and risks of modern technology often objects the claim for justice of sustainability - for example: industrialized countries are often the beneficiaries of technological innovations, while developing countries are primarily affected by the disadvantages. The "digital divide", describing not only the unequal opportunities to use the Internet in industrialized compared to developing countries but also within industrialized countries is an often quoted example (Grunwald et al., 2006).

On the other hand, there are also many impacts and consequences of technological progress which are positive in the sense of sustainability. Well-known examples are the prosperity which has been achieved in many parts of the world and the consequential security of livelihood and quality of life, the successful control of many diseases which were disastrous in former times, food security in many (not all!) parts of the world, and the possibility of global information and communication through the Internet. Innovative technologies play a key role in the so-called efficiency strategies of sustainable development (cf. e.g. Weizsäcker et al., 1995). To some extent, modern technologies can already replace conventional technologies and thus contribute to more sustainability (e.g. by fewer emissions and reduced consumption of resources).

This ambivalent relation between technology and sustainability is the starting point for approaches for shaping technology and its societal ways of use (Weaver et al., 2000). These approaches shall be used to realize the positive sustainability effects of innovative technology and minimize or avoid the negative ones in order to contribute through technological progress to a sustainable development in an optimal way. The resulting question is not whether technological progress has positive or negatives effects on sustainability, but how scientific-technological progress and the use of its results has to be designed to achieve positive contributions to a sustainable development. The questions which have to be analysed in this context include:

- How and to which extent can research, development, and use of new technologies contribute to sustainability? How do technology's contributions to sustainability influence other contributions (e.g. of changing lifestyles and a "sustainable consumption")? Within which period of time can the impacts relevant for sustainability be expected?

- Which societal framework conditions can serve as incentive for the development, production, and market integration of innovative technology as a contribution to more sustainability? Which political instruments can support this?

- Which methods can be used to assess whether and to which extent the use of technology can result in more or less sustainability? Which sustainability criteria can be the basis for these assessments and how are they justified? Where are methodological new or further developments necessary, e.g. in life cycle analysis?

- Which standards of comparison, weighing principles, and criteria for consideration can be used in situations of contrary effects and conflicts of aims concerning sustainability?

- How reliable or arguable are sustainability assessments of technology? How should be dealt with the unavoidable uncertainty and ambivalence concerning the knowledge on impacts and assessment problems? 
The structure of these questions is very similar to that of the types of tasks of technology assessment (TA) (Grunwald, 2009). In the end it is about prospectively understanding and assessing technology impacts relevant for sustainability - preferably already during the development of a technology. The principle of considering such knowledge on presumable or probable technology impacts already in the early stages of decision-making and making it thus usable for the design of technology itself or its societal "embedment" is part of the basic concept of TA. Therefore the experience of TA can be used to answer the above-mentioned questions of a prospective sustainability assessment of technology (Fleischer \& Grunwald, 2002). In this context the requirements for sustainability assessments and their consideration for decision-making processes are accompanied by considerable conceptual and methodological challenges, even regarding the ambitious concepts of TA. It is no exaggeration to say that the well-known methodological problems of technology assessment concerning both future prospects and evaluation are taken to extremes here.

Several experiences have already been made in applying ideas of TA to shaping technology assessment for sustainable development. There many different opportunities, contexts, situations, stage of development of the respective technologies but also different challenges, obstacles and difficulties. Within this spectrum we can identify two extremes:

a. The transformation of large infrastructures (such as energy supply, water supply, information and communication, and transport) toward more sustainable structures. The issues at stake in this respect is that usually a system transformation will be needed where singular technologies are only parts of the game but where social issues, acceptance, user behaviour, governance, power and control are main elements.

b. New and emerging science and technologies (NEST) such as nanotechnology, microsystems technologies, converging technologies and synthetic biology are enabling technologies: they can lead to a lot of revolutionary developments in many application areas. Therefore, they often show high potentials for supporting strategies of sustainable development - however, most of them are related also with high uncertainties and possible risks.

In the following, two examples are briefly introduced to illustrate the differing challenges with respect to sustainability assessments and the elaboration of strategies: the transformation of the energy system as an example for infrastructures and the case of nanotechnology as an example for NEST cases.

(a) The transformation of the energy infrastructure in conjunction with principles of sustainable development is a considerable challenge. Industrialized countries such as Germany have achieved high standards of energy supply. Energy in the form of electricity, gas, or fuel is reliable and has been more or less available to industrial and private consumers without restriction for decades. Changes in these framework conditions can easily lead to societal controversies. Therefore, transformation processes must always take into account the willingness of customers and users to support these changes and implement behavioral adaptations where required. Sustainability assessments of technology therefore must include the 'social side' of the technologies. The energy supply infrastructure is a socio-technical system. It can only fulfill its function if supply and demand are balanced, and if the required changes can be integrated into the existing routines of functioning societal processes, or if new routines can be easily established. Therefore, not only is 
technical competence necessary for the analysis and design of future (sustainable) energy infrastructures, but so are insights into organizational and societal circumstances such as political-legal framework conditions, economic boundary conditions, individual and social behavior patterns, ethical assessment criteria, and acceptance patterns. In addition, other infrastructures must be co-considered with the energy system: in particular the transport infrastructure (through the development towards e-mobility) and the information infrastructures. The interplay between technical potential, complex social usage patterns, and connected regulation and control processes requires a holistic investigation and an interdisciplinary assessment of the transformation-and-governance strategies aiming at sustainable development. Sustainability assessment of new energy infrastructure elements, therefore, must not be restricted to exploring the supply side and to the provision of technical artifacts (machines, power stations, pipelines etc.). Instead, sustainability assessments must consider also the societal demand and user side. Research must bridge disciplinary boundaries between the natural, technical, and social sciences and link technical developments to context conditions of markets, organizational strategies and individual behavior. Multiple interfaces between technical, environmental and social issues have to be taken into account.

(b) The situation in the NEST case is completely different. NEST may change products, systems, and value added chains in many different application fields. There is much more open space for shaping technology because of the early stage of development. The main (research) questions for a sustainability assessment of nanotechnologies are (Fleischer \& Grunwald, 2008): Can nanotechnology development and the application of the resulting products, processes and systems be organized in a sustainable - or, at least, more sustainable - manner? How can nanotechnologies and their application paths be shaped in a way that they positively contribute to sustainable development? Are there possibilities of shaping nanotechnologies already in early stages of R\&D? The application of nanotechnology in products and systems is expected to produce a significant relaxation of the burden on the environment: a saving of material resources, a reduction in the mass of by-products that are a burden on the environment, improved efficiency in transforming energy, a reduction in energy consumption, and the removal of pollutants from the environment (Fleischer \& Grunwald, 2008). A number of studies on precisely the issue of the sustainability of nanotechnology have been published in the meantime (e.g., JCP, 2008). However, these developments might have a price. The consequences of the use and release of nanomaterials into the environment are unknown. Although it is not very probable that synthetic nanoparticles in the environment will have long-term effects because of anticipated agglomeration processes, there is no proof available. We do not know about possible longterm effects comparable to the HCFC problem that created the hole in the ozone layer. This situation of high uncertainty and ignorance places a burden of possible risk on future generations while we are exploiting the benefits of nanotechnology today.

Shaping nanotechnologies for sustainable development requires anticipatory sustainability assessments in order to permit distinctions to be made between the more and less sustainable technologies (Fleischer \& Grunwald, 2008). Anticipatory assessments of nanotechnology have to cover the entire life cycle of the respective technological products or systems. They should include a temporal integration and balancing of all sustainability effects which might occur during the complete life cycle. For such analyses to contribute to shaping nanotechnologies for more sustainability, they must provide reliable prospective life cycle 
information, such as on health and environmental implications, consumption and production patterns, future developments of lifestyles and markets, and the political and economic framework conditions for the later usage of new technologies. These are only some examples of aspects of the future that need to be known in advance in order for reliable life cycle analyses to provide sustainability assessments. A start has already been made toward addressing this challenge for the creation of prospective life cycle assessment. The increasing focus on life cycle assessment as a tool for example in strategy and planning processes, including for long-term issues, and in scenario processes has triggered methodological developments that try combine traditional technology foresight methods with life cycle assessment methods (Schepelmann et al., 2009). Decisive for a comprehensive assessment of nanotechnology or of the corresponding products from a sustainability point of view is that the entire course of the products lifetime is taken into consideration. This extends from the primary storage sites to transportation and the manufacturing processes to the product's use, ending finally with its disposal (Fleischer \& Grunwald, 2002). In many areas, however, nanotechnology is still in an early phase of development, so that the data about its life cycle that would be needed for life cycle assessment are far from being available. Empirical research on the persistence, long-term behaviour, and whereabouts of nanoparticles in the environment as well as on their respective consequences would be necessary to enable us to act responsibly in accordance with criteria of sustainable development.

These examples show the high variety of methodological and governance challenges, reaching from societal inertia with respect to the transformation of infrastructures to severe uncertainties in the NEST case, followed by a large gap between far ranging expectations and dystopian fears (Grunwald, 2007). With respect to sustainable development it has to be stated that there is a high diversity of understandings governing the respective sustainability assessments. This diversity endangers the validity of any sustainability assessment because any of them could be regarded arbitrary. Also comparisons between different sustainability assessments will be difficult or impossible because of incommensurable sustainability understandings. A comprehensive framework is still missing - in the following such a framework will be introduced and proposed to be used as an overall sustainability assessment framework (Sec. 4).

\section{Technology Assessment and its addresses}

Technology Assessment constitutes a scientific and societal response to problems at the interface between technology and society (Grunwald, 2009). It has emerged against the background of various experiences pertaining to the unintended and often undesirable side effects of science, technology, and technicization which, in modern times, can sometimes assume extreme proportions (Bechmann et al., 2007). The types of challenges that have evolved for TA are these: that of integrating at an early stage in decision-making processes any available knowledge on the side effects, that of supporting the evaluation of the value of technologies and their impact, that of elaborating strategies to deal with the knowledge uncertainties that inevitably arise, and that of contributing to the constructive solving of societal conflicts on technology and problems concerning technological legitimization. What characterizes TA is its specific combination of knowledge production (concerning the development, consequences, and conditions for implementing technology), the evaluation of 
this knowledge from a societal perspective, and the recommendations made to politics and society. The overall aim of TA is to "make a difference" which means to create real influence on the ongoing process of technology development and use. In this sense, sustainability assessment of technologies mustn't be a distant and purely analysing activity but has to be regarded an actor in the field. This situation of TA being an observer and analyst in combination with taking an active role in technology governance results in particular requirements for methodological clarity, quality assurance, and transparency in any respect, in particular regarding the values involved. In addition this situation implies that TA has to be aware of ongoing projects also during the lifetime of TA projects (see Fig. 1).

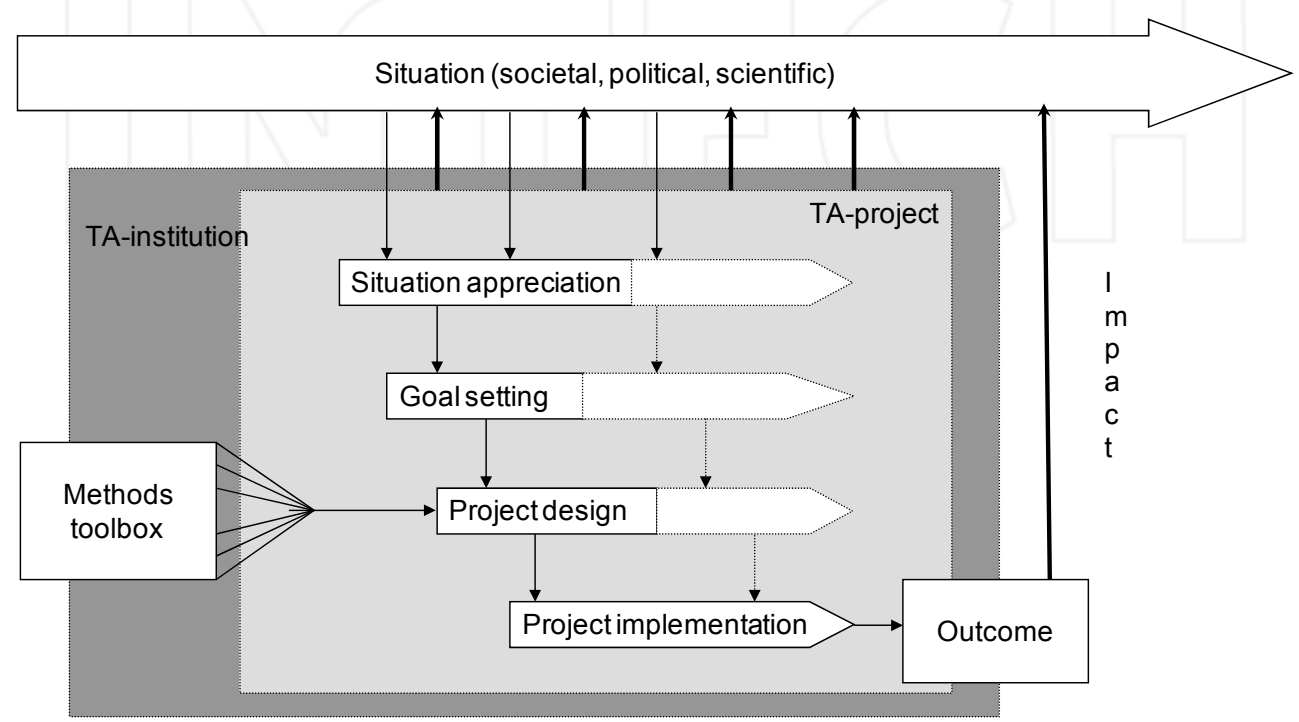

Fig. 1. TA influencing the ongoing societal situation by concrete TA projects continuously keeping track with developments at the societal level (Decker \& Ladikas 2004).

Governance of technology has become much more diverse and complex over the past decades. While in earlier times (in the "classical mode" of TA, cp. Grunwald 2009a) a strong role of the state was supposed nowadays much more actors and stakeholders are regarded as being influential on the development and use of new technologies: companies, consumers, engineers, non-governmental organisations (NGO), stakeholders of different kind and citizens. Depending on their roles and occasions to take influence the advice provided by TA could or should look different - in this sense the shift from "steering technology" to a "governance of technology" has had a major influence on TA. Theories of technology development and governance could provide orientation for TA whom to address and what to deliver. Technology assessment with respect to sustainable development will have to consider this variety of actors and stakeholders in being effective and efficient.

The political level remains a major player since governmental technology policy creates obligations for everyone with (partially) high influence on technology. Policy consultation by TA can, for example, take place in the preparatory phase of legislation relevant to 
technology or even in the very early phases of opinion-forming in the political parties. In the run-up to policy decisions it is possible for TA to carry out enlightenment by reflecting on possible consequences and impacts of technology on society and on the values touched. This positioning of TA research and consultation affects all constellations in which state action influences technology including direct state-run or at least state-dominated technology development, for example in the fields of space travel, military technology, and transportation infrastructure; indirect political influence on technology by means of programs promoting research and technology, for example in materials science, on regenerative sources of energy, or in stem cell research; indirect political control of technology by setting boundary conditions such as environmental and safety standards, laws on privacy or laws stipulating recycling and the role of the state as a user of technology, e.g., with regard to the observance of sustainability standards (public procurement). In all of these fields issues relevant to sustainable development play an important role. In some countries this situation already led to the obligation to perform a sustainability assessment of new laws.

TA gives advice to policy-makers in all of these fields and to the involved organisations such as parliaments, governments, and authorities. An example is the Office of Technology Assessment at the German Bundestag (TAB: http://www.tab-beim-bundestag.de). The purpose of the $\mathrm{TAB}$ is to provide contributions to the improvement of the legislature's information basis, in particular, of research- and technology-related processes of parliamentary discussion. Among its responsibilities are, above all, drawing up and carrying out TA projects, and - in order to prepare and to supplement them - observing and analyzing important scientific and technical trends, as well as societal developments associated with them (monitoring). The TAB is strictly oriented on the German Bundestag's and its committees' information requirements. The choice of subjects for TA projects as well as their delimitation and specification is the Bundestag's responsibility. Decisions on the urgency of problems and the scientific advice desired belong on the political agenda. The subjects of the TAB's studies stem from all fields of technology. The "classical" TA subjects, such as technology and the environment, energy, and bio- and genetic engineering, predominate, involving challenges of sustainable development to an increasing extent over the last years.

The concrete development of technology, however, takes place primarily in the economy at market conditions. The shaping of technology by and in enterprises is operationalized by means of requirement specifications, project plans, and strategic entrepreneurial decisions. These in turn take place on the prescriptive basis of an enterprise's headline goals, general principles, plan goals, and self-understanding but also including assumptions about later consumers and users of the technology and future market conditions. Engineers and engineering scientists have influence on decisions at this level and are confronted in a special way with attributions of responsibility because of their close links with the processes of the development, production, utilization, and disposal of technology. Technology assessment became aware of the importance of this part of technology governance in the 1980s in the course of the social constructivist movement leading to the slogan of "shaping technology" (Bijker et al., 1987; Bijker \& Law, 1994). In particular, the approach of Constructive Technology Assessment (CTA, cp. Rip et al., 1995) took up ideas of shaping technology according to the requirements of sustainable development. 
The individual preferences of users and consumers of technical systems and products help determine the success of technology developments in two ways: first, by means of their purchasing and consumer behaviour, and second (and less noted), by means of their comments in market research. The influence on technological development resulting from consumer behaviour arises from the concurrence of the actual purchasing behaviour of many individual persons. A well-known problem is, for example, that awareness of a problem with regard to the deficient environmental compatibility of certain forms of behaviour - though definitely present - may not lead to a change in behaviour. Technology assessment aims, in this field, at public enlightenment and information about consequences of consumer's behaviour and at enabling and empowering individuals to behave in a better reflected way, in particular towards more sustainable consumption patterns..

The course of technical development is also decided by public debates, above all by those in the mass media. Public discussion in Germany influenced, for example, political opinion on atomic energy, thus providing much of the basis for the decision in 2002 to phase out atomic energy in that country, and to return to this position after a more positive appraisal of nuclear energy after the Fukushima disaster. Similarly, the public discussion about genetically modified organisms has influenced the regulatory attitude of the European Union and the official acceptance of the precautionary principle. This can also be recognized by the fact that different regulations were established in those countries in which the public debates were very different, such as in the USA. Technology assessment has become an actor also in this field by involving itself in participatory processes playing an increasing role also in political decision-making processes in many countries, in particular in relation with sustainability issues.

\section{The integrative sustainability concept}

There is considerable need for orientation knowledge on how to fill the Leitbild of sustainable development with substance conclusively as soon as it is expected to guide the transformation of societal systems, e.g. the energy system. To gain practical relevance, some essential criteria have to be fulfilled: (1) a clear object relation, i.e. by definition it must be clear what the term applies to and what not, and which are the subjects to which assessments should be ascribed; (2) the power of differentiation, i.e. clear and comprehensible differentiations between "sustainable" and "non- or less sustainable" must be possible and concrete ascriptions of these judgements to societal circumstances or developments have to be made possible beyond arbitrariness; (3) the possibility to operationalize, i.e. the definition has to be substantial enough to define sustainability indicators, to determine target values for them and to allow for empirical "measurements" of sustainability.

The integrative concept (see Kopfmüller et al., 2001) identified three constitutive elements of sustainable development out of the famous Brundtland Commission's definition (WCED, 1987), taking into account also results of the World Summit at Rio de Janeiro 1992 and from ongoing scientific results and debates. These three elements are (1) the global perspective, (2), the justice postulate and (3) the anthropocentric point of departure.

(1) An essential aspect of sustainable development is, first of all, the global orientation. The assignment given the Commission by the UN General Assembly was that "a global agenda for change" was to be formulated to help define" the aspirational goals for the world 
community", and how they could be realized through better cooperation "between countries in different stages of economic and social development" (WCED, 1987). The Commission's report is based on a fresh view of the problems, which interprets the phenomenon of global environmental deterioration and the growing prosperity gap between North and South as interrelated crises of modern industrial society. On the basis of this understanding of the problem, the Commission elaborates the concept of sustainable development as a sound, long-term model for the survival and welfare of global society. The chances for overcoming the global crisis, in their view, depend on the extent to which we succeed in making this concept a model for a "global ethic" (WCED, 1987). On the basis of the general consensus arrived at in the Commission on the prerequisites for global sustainable development, the individual nations are supposed to elaborate on the national level specific targets and strategies for realizing the general objectives, which would be adapted to their own respective current circumstances.

(2) The most important criterion for sustainability is, from the viewpoint of the Brundtland Commission, that of justice. Fundamental for their interpretation of justice is, first of all, the mutual interdependence of intra- and intergenerational justice: a just(er) present is the prerequisite for a just future. In this case, "justice" is primarily defined as distributive justice. The present inequalities of distribution as regards access to natural resources, income, goods and social status is regarded to be the cause of global problems and conflicts, and a juster distribution or rather, a re-distribution of rights, responsibilities, opportunities, and burdens is required. The integrative concept is, following and concretizing this line of thought, based on the postulate that - following Rawls - every human being has a right of access to certain basic goods, which are indispensable preconditions for a self-determined life. Every human being is entitled to these rights and goods, independent of his or her accomplishments, and regardless of circumstances, for which he or she is not to be held accountable. The guarantee of human rights in their entirety is seen as a precondition for, rather than the content of sustainable development. In view of the difficulties of prognosticating the needs of future generations, keeping options open, or, rather, upholding possible choices for future generations is seen as a basic requirement of intergenerational justice. In contrast to other concepts, which regard only the responsibility for future generations as constitutive for sustainability (s. above), inter- and intragenerational justice are here held to be related and, normatively, equal in rank. If one - on the basis of the principle of responsibility for future generations - postulates that access to certain primary goods has to be ensured throughout time, one must also expect that these basic goods are made accessible to all humans today. Otherwise, one would demand - in the interest of future generations - the awarding of rights which are denied to the present generation.

(3) The third element which is characteristic for the Brundtland Report's understanding of sustainability is the anthropocentric orientation. The satisfaction of human needs is, in this concept, the primary goal of sustainable development - today, and in the future. The conservation of nature is not taken as an objective in its own right, but as a prerequisite for lasting societal progress - that is to say, nature is seen as a means to mankind's ends. Humanity is responsible for nature, because humans, as natural beings, are dependent on certain ecosystem services, on the functioning of natural cycles and growth processes. Even when nature is attributed intrinsic value as living space and as a source of experiences, this is done from the viewpoint of, and according to the standards of, human beings. Like most of the other concepts of sustainability, the integrative concept is based on a position of 
"enlightened" anthropocentrism which justifies the responsibility for a cautious utilization of nature with mankind's own well-understood self-interest. The responsibility of preserving the diversity of options for human interaction with nature for the future follows out of the postulate that the same rights are to be granted to future generations as the present one enjoys.

These constitutive elements are operationalized further in two steps: first, they were "translated" into the three general goals of sustainable development (1) securing human existence, (2) maintaining society's productive potential (comprising natural, man-made, human, and knowledge capital), and (3) preserving society's options for development and action. In a second step, these goals are concretized by sustainability principles, which apply to various societal areas or to certain aspects in the relationship between society and nature. The concept distinguishes between substantial principles, identifying minimum conditions for sustainable development that ought to be assured for all people living in present and future generations (see table 1a - 1c), and instrumental principles, describing necessary framework conditions for the realization of the substantial minimum conditions (see table 2). On the one hand, these principles - to be further concretized by suitable indicators - unfold the normative aspects of sustainability as goal orientation for future development and as guidelines for action; on the other hand they provide criteria to assess the sustainability performance of particular societal sectors, spatial entities, technologies, policies, etc.

It seems quite important for the understanding of the concept and its consequences for Sustainability Technology Assessment (cp. next Section) to explain the relation between the super-ordinate goals and the principles more in-depth, in particular to give arguments for the determination of the sustainability principles (following Brandl et al. 2002). This will be done in the following. An overview of the substantial principles is given in Figures 1a - 1c. The numbers of the principles mentioned in the following sections refer to the structure of the tables in order to allow for a quick overview.

\begin{tabular}{|l|l|}
\hline $\begin{array}{l}\text { 1.1 Protection of human } \\
\text { health }\end{array}$ & $\begin{array}{l}\text { Hazards and unacceptable risks to human health due to } \\
\text { anthropogenic environmental burdening must be avoided. }\end{array}$ \\
\hline 1.2 Ensuring basic needs & $\begin{array}{l}\text { Every member of society must be assured a minimum of } \\
\text { basic supplies (housing, food, clothing, health care) and } \\
\text { protection against fundamental risks to life (sickness, } \\
\text { disability). }\end{array}$ \\
\hline $\begin{array}{l}\text { 1.3 Securing an autonomous } \\
\text { existence }\end{array}$ & $\begin{array}{l}\text { All members of society must be given the possibility of } \\
\text { securing their existence by voluntarily undertaken activities } \\
\text { (including education of children and care of the elderly). }\end{array}$ \\
\hline $\begin{array}{l}\text { 1.4 Fair sharing in the use of } \\
\text { natural resources }\end{array}$ & $\begin{array}{l}\text { Utilization of natural and environmental resources must } \\
\text { be distributed according to the principles of justice and a } \\
\text { fair participation of all persons affected. }\end{array}$ \\
\hline $\begin{array}{l}\text { 1.5 Balancing extreme } \\
\text { inequalities in income and } \\
\text { wealth }\end{array}$ & $\begin{array}{l}\text { Extreme inequalities in the distribution of income and } \\
\text { wealth must be reduced. }\end{array}$ \\
\hline
\end{tabular}

Table 1. a. Substantial sustainability principles related with the general sustainability objective "Securing human existence" according to the integrative sustainability concept. Source: Kopfmüller et al., 2001 (translated). The left column contains the short title, the right one the principle. 


\section{(1) Securing Mankind's Existence}

The prime necessity which can be derived from the postulate of justice is, without doubt, that the present generation shouldn't destroy the basis of its own subsistence and that of future generations. A fundamental precondition for this aim is, first of all, that the environmental conditions necessary for human health are upheld. This comprises, in particular, the responsibility of minimizing impacts on the environment which can also impair human health (Principle 1.1). Besides health protection, the satisfaction of basic needs is seen as an indispensable prerequisite for an adequate human existence. These are nourishment, clothing, shelter, basic medical care, access to pure drinking water and to sanitary facilities, as well as safeguards against crucial existential hazards, such as illness, disability, and social crises (Principle 1.2). With respect to sustainable development, the goal can, however, not merely consist in securing "naked existence", but must rather include the best possible preparation for individuals to plan their lives themselves in an active and productive manner. The minimum prerequisite for this empowerment is, that all members of society have the opportunity to secure an adequate and stable existence, including the education of children and provision for old age, by means of an occupation chosen of their own free will (Principle 1.3). While the responsibility of satisfying basic needs is reduced to the material core of the vitally necessary goods, this principle, formulated according to Amarthya Sen, is directed at the presuppositions for a self-determined life. The purpose is to enable people to provide themselves with everything they need, instead of their merely being provided through transfer payments or other external assistance. Providing the basis for an independent livelihood presupposes, in its turn, that access to the necessary resources is assured. A necessary condition for this purpose is a just distribution of the opportunities for making use of the globally accessible environmental goods (the earth's atmosphere, the oceans, water, biodiversity, etc.) with the fair participation of all concerned (Principle 1.4). The postulate of ensuring acceptable living conditions and autonomous self-support also implies, finally, that extreme differences in income and wealth be compensated as well as possible (Principle 1.5). This last principle reiterates the previous one with regard to the distribution of income and wealth. This has to be just, at least inasmuch as extreme poverty, which makes active participation in social life impossible, and would lead to social exclusion, has to be precluded.

\section{(2) Maintaining Society's Productive Potential}

Future generations should find comparable possibilities of satisfying their needs, which mustn't necessarily be identical to those of the present generation. Regarding the material needs, one can derive from this postulate the requirement that the productive capacity of (global) society has to be upheld through time - in a quite general sense - as a generic goal of sustainable development. Every generation disposes over a certain productive potential, which is made up of various factors (natural capital, real capital, human capital, knowledge capital). Sustainable development demands in general, that the stock of capital which exists within a generation be handed down as undiminished as possible to future generations whereby, however, two fundamentally different alternatives are conceivable (cf. Daly, 1999, p. 110ff.). On the one hand, one could stipulate that the sum of natural and human-made capital be constant in the sense of an economy-wide total; on the other hand, one could require that every single component of itself has to be preserved intact. The former path is sensible if one assumes that natural and human-made capital are interchangeable (weak 
sustainability). The latter path is advisable if one assumes that human-made and natural capital stand in a complementary relationship to one another (strong sustainability). The controversy over both of these strategies, that is, over the question, how the heritage which is to be handed down to future generations should be composed, is one of the central problems of the sustainability debate (cf. Ott/Döring 2004). In the integrative concept the substitution of natural capital by human-made capital is held to be admissible to a limited extent, as long as nature's basic functions (the immaterial ones as well) are maintained. With regard to renewable resources, it stipulates that the rate of their use shouldn't exceed the rate of their regeneration, whereby the manner of use is to be taken into consideration along with the intensity of use (Principle 2.1). With reference to non-renewable resources, it assumes that it isn't possible to abstain from their use entirely, but that their consumption has to be compensated. The approach postulates that the range of the known non-renewable resources remains constant through time (Principle 2.2). This principle can only be kept if we either abstain from consuming these resources (sufficiency), if resource productivity is increased (efficiency), if non-renewable resources are replaced by renewable resources (consistency), or if new reserves are tapped. In order to maintain the functions of stabilization and support indispensable for humanity, it requires that the anthropogenic material input should not exceed the absorptive capacity of the environmental media and of the ecosystems (Principle 2.3). To complement these three principles on the use of nature, the integrative concept postulates further that technical hazards with possibly catastrophic effects on human beings and on the environment are to be avoided (Principle 2.4). The formulation of this sort of principle was felt to be necessary, because the risk component is only insufficiently comprehended by the other principles. Setting limits, for example, in fact requires, regarding the maximum pollutant level in environmental media, the weighing of risks; this, however, orients itself, in general, on "trouble-free, normal operation", and leaves the possibility of breakdowns - to a great extent - out of consideration. With regard to the general goal of maintaining society's productive potential, finally, the integrative concept postulates developing real, human and knowledge capital so, that economic efficiency is

\begin{tabular}{|l|l|}
\hline $\begin{array}{l}\text { 2.1 Sustainable use of } \\
\text { renewable resources }\end{array}$ & $\begin{array}{l}\text { The rate of utilizing renewable resources is not to exceed } \\
\text { the regeneration rate or endanger the ecosystems' } \\
\text { capability to perform and function. }\end{array}$ \\
\hline $\begin{array}{l}\text { 2.2 Sustainable use of non- } \\
\text { renewable resources }\end{array}$ & $\begin{array}{l}\text { The range of proved non-renewable resources must be } \\
\text { maintained. }\end{array}$ \\
\hline $\begin{array}{l}\text { 2.3 Sustainable use of the } \\
\text { environment as a sink for } \\
\text { waste and emissions }\end{array}$ & $\begin{array}{l}\text { The release of substances is not to exceed the absorption } \\
\text { capacity of the environmental media and ecosystems. }\end{array}$ \\
\hline $\begin{array}{l}\text { 2.4 Avoiding unacceptable } \\
\text { technical risks }\end{array}$ & $\begin{array}{l}\text { Technical risks with potentially catastrophic impacts on } \\
\text { humanity and the environment must be avoided. }\end{array}$ \\
\hline $\begin{array}{l}\text { 2.5 Sustainable development } \\
\text { of man-made, human, and } \\
\text { knowledge capital }\end{array}$ & $\begin{array}{l}\text { Man-made, human, and knowledge capital must be } \\
\text { developed in order to maintain or improve the economy's } \\
\text { performance. }\end{array}$ \\
\hline
\end{tabular}

Table 1.b. Substantial sustainability principles related with the general sustainability objective "Maintaining society's productive potential" according to the integrative sustainability concept. Source: Kopfmüller et al., 2001 (translated). The left column contains the short title, the right one the principle. 
upheld or improved (Principle 2.5). Above all, with regard to real capital, the concept of "development" used here not only includes the possibility of conservation or adaptation, in the sense of building up or restructuring, but, where possible, of reduction as well. The criteria for these decisions follow out of the application of the other principles formulated here.

\section{(3) Keeping Options for Development and Action Open}

The precept of not endangering the satisfaction of future generations' needs can, however, not be limited to material necessities but has to include immaterial needs as well. For human existence, immaterial aspects such as integration in social and cultural relationships, communication, education, contemplation, aesthetic experiences, leisure, and recreation are just as indispensable as the material bases of subsistence and just as important. Only when these needs have also been satisfied can one speak of a stable and acceptable level of human existence. With regard to the individual human being, this means that the opportunities for personal development have to be secured in the present and for the future. A minimum prerequisite for attaining this goal would be, first of all, the guarantee of equal opportunity in access to education, information, culture, to an occupation, to public office, and to social status (Principle 3.1). Free access to these goods is seen as the basis for equal opportunity for all members of society to develop their own talents and to realize their life plans. As a basic precondition for a self-determined life, equal opportunity is, at the same time, a necessary prerequisite for meeting the demand for autonomously earning one's own living (s. above, Principle 1.3). The second indispensable minimum requirement is the opportunity for participation in societally relevant decision-making processes (Principle 3.2). The basis for this principle is the conviction that a society can only then be considered sustainable - in normative as well as functional respect - when it offers its members the chance for participation in the formation of societal volition. Its purpose is to uphold, broaden, and improve democratic forms of decision-making and conflict management, especially in view of decisions which are of critical importance for the future development and organization of society. In the concept of sustainability, participation is a means as well as an end: with regard to the individual's right to a self-determined life, participation is a goal. Proceeding on the conviction that a process of development in the direction of sustainability can only then be successful, if it is initiated and supported by a broad societal basis, participation is, at the same time, an instrument. With regard to the general goal of not restricting future generations' options for development and action, one would have to raise the further demand that present options also shouldn't be restricted. A minimum requirement for this purpose is that the historical heritage, as well as the diversity of cultural and aesthetic values is preserved (Principle 3.3). This precept includes the protection of nature above and beyond its economic function as a source of raw materials and as a sink for pollutants: nature, resp., certain elements of nature, have to be protected because of their cultural importance as an object of contemplative, intellectual, religious, and aesthetic experiences (Principle 3.4). The minimum requirements listed above primarily refer to the interests of individual members of society, while the aspect of the social system or of society as a whole remained to a great extent left aside. The expectations of individuals with regard to selfactualization and autonomy, however, don't necessarily harmonize with society's demands for integration, stability, and conformity. In the interest of sustainable development, this conflict relationship has to be balanced out. A society which wants to remain lastingly viable has to provide for the integration, socialization, participation, and motivation of its 
members, and have the capability of appropriate reaction to changed circumstances. A minimum requirement for securing society's cohesion is seen in maintaining its "social resources". This means that tolerance, solidarity, a sense of civility and justice, as well as the capability for the peaceful resolution of conflicts have to be improved (Principle 3.5).

\begin{tabular}{|l|l|}
\hline 3.1 Equal opportunities & $\begin{array}{l}\text { All members of society must have equal chances to access } \\
\text { education, occupation, information, and public functions } \\
\text { as well as social, political, and economic positions. }\end{array}$ \\
\hline $\begin{array}{l}\text { 3.2 Participation in societal } \\
\text { decision-making processes }\end{array}$ & $\begin{array}{l}\text { Every member of society should be given the opportunity } \\
\text { to participate in relevant decision-making processes. }\end{array}$ \\
\hline $\begin{array}{l}\text { 3.3 Conservation of cultural } \\
\text { heritage and diversity }\end{array}$ & $\begin{array}{l}\text { Human cultural heritage and cultural diversity must be } \\
\text { preserved. }\end{array}$ \\
\hline $\begin{array}{l}\text { 3.4 Conservation of the } \\
\text { cultural function of nature }\end{array}$ & $\begin{array}{l}\text { Cultivated and natural landscapes or areas of special } \\
\text { uniqueness and beauty have to be preserved. }\end{array}$ \\
\hline $\begin{array}{l}\text { 3.5 Conservation of social } \\
\text { resources }\end{array}$ & $\begin{array}{l}\text { To ensure societal cohesion, the sense of legal rights and } \\
\text { justice, tolerance, solidarity, and perception of common } \\
\text { welfare as well as the possibility of non-violent conflict } \\
\text { settlement must be enhanced. }\end{array}$ \\
\hline
\end{tabular}

Table 1.c. Substantial sustainability principles related with the general sustainability objective "Preserving development and action options" according to the integrative sustainability concept. Source: Kopfmüller et al., 2001 (translated). The left column contains the short title, the right one the principle.

The basic orientation of the fifteen substantial principles is influenced by the three general sustainability objectives assigned to them. The general objective 'Securing human existence' focuses on the individual as being the prime beneficiary. The general objective 'Maintaining society's productive potential' refers to the indispensable prerequisites of various societal activities and is by no means limited to the material prerequisites for the conventional production of goods and services in the private and public sector. According to the general objective 'Preserving development and action options' the current generation is, if it can, required to establish and preserve the prerequisites for the freedom of decision by future generations.

The fifteen substantial principles collectively represent minimum requirements and may be complemented by additional requirements, provided the original principles are not violated. The substantial principles may be fulfilled to different degrees. If, however, two of them are in conflict, they will have to be weighed up. In the general model, the instrumental principles are indispensable and equal the substantial principles.

Conflicts of goals between principles can exist on different levels. First of all, it cannot be excluded that the formulated working hypothesis of a simultaneous satisfiability of all principles will be falsified. Undiminished population growth, for instance, could lead to such a falsification, if satisfaction of basic needs of the world population would not be possible without breaking e.g. the natural resource-related principles. Other conflict potentials can arise when the guiding principles are translated into concrete responsibilities of action for societal actors. In such conflicts, each principle can be valid only within the limits set by the others. Additionally, the concept includes a weighing principle by 
distinguishing between a core scope for each principle which always has to be fulfilled and may not be weighed against other principles, and a rather peripheral scope where weighing is possible. Regarding for instance the principle "Ensuring satisfaction of basic needs", the core scope would be the pure survival of everyone, whereas the peripheral scope would have to be defined, to a certain extent according to particular regional contexts.

\begin{tabular}{|c|c|}
\hline $\begin{array}{l}\text { Internalization of environmental } \\
\text { and social external costs }\end{array}$ & $\begin{array}{l}\text { Environmental and social external costs arising } \\
\text { in an economic process must be considered } \\
\text { within this process. }\end{array}$ \\
\hline \multirow[t]{2}{*}{ Appropriate discounting } & \multirow{2}{*}{$\begin{array}{l}\text { Discounting may not discriminate against future } \\
\text { or present generations. }\end{array}$} \\
\hline & \\
\hline Limiting public indebtedness & $\begin{array}{l}\text { In order to avoid restricting the state's future } \\
\text { action and design scope, in principle current } \\
\text { public consumption expenditures must be } \\
\text { funded by current income. }\end{array}$ \\
\hline Fair global economic framework & $\begin{array}{l}\text { The global economic framework conditions } \\
\text { should be designed so that economic actors of all } \\
\text { states have the fair chance to participate in } \\
\text { economic processes. }\end{array}$ \\
\hline $\begin{array}{l}\text { Enhancing international co- } \\
\text { operation }\end{array}$ & $\begin{array}{l}\text { The various actors (governments, enterprises and } \\
\text { non-governmental organizations) must co- } \\
\text { operate in the spirit of global partnership in } \\
\text { order to create the political, legal, and factual } \\
\text { prerequisites for implementing sustainable } \\
\text { development. }\end{array}$ \\
\hline Society's ability to respond & $\begin{array}{l}\text { Society's ability to respond to problems in the } \\
\text { natural and societal spheres must be enhanced } \\
\text { by suitable institutional innovations. }\end{array}$ \\
\hline Society's ability to reflect & $\begin{array}{l}\text { Institutional conditions must be developed, } \\
\text { which allow reflection on societal action options } \\
\text { beyond isolated problems and individual } \\
\text { aspects. }\end{array}$ \\
\hline Ability to steer & $\begin{array}{l}\text { Society's ability to steer towards a sustainable } \\
\text { development must be increased. }\end{array}$ \\
\hline Self-organization & $\begin{array}{l}\text { The self-organization potential of societal actors } \\
\text { has to be enhanced. }\end{array}$ \\
\hline Balancing power & $\begin{array}{l}\text { Opinion-building, negotiation, and decision } \\
\text { processes must be designed so that the } \\
\text { possibilities of societal actors to express } \\
\text { themselves and exert influence are justly } \\
\text { distributed and the processes are transparent. }\end{array}$ \\
\hline
\end{tabular}

Table 2. Instrumental principles according to the integrative sustainability concept. Source: Kopfmüller et al., 2001 (translated)

The conflict potential included in the sustainability principles shows that even an integrative concept is not harmonistic. Rather, the integrative nature of sustainability increases the 
number of relevant conflicts. This approach is able to uncover those - otherwise hidden conflicts in defining and implementing sustainable development. Thus, conflicts are by no means to be avoided but rather are at the heart of any activities to make sustainability work (Grunwald, 2005). Rational conflict management and deliberation are, therefore, of great importance.

Sustainable development remains a political and normative notion also in the scientific attempts of clarification and operationalization. Therefore, it will not be possible to provide a kind of "algorithm" for sustainability assessments allowing for calculating an objective "one best solution" of sustainability challenges. What can be done, however, is to clarify the framework for assessments and societal decision-making to support transparent, wellinformed, and normatively-orientated societal processes of deliberation on sustainability.

\section{Sustainability principles to be applied in technology assessment}

The integrative sustainability concept has not been specifically developed as an instrument for technology assessment but refers to the development of society as a whole in the global perspective. However, technology is always just one component of societal relations and developments; many other and sometimes more relevant aspects - like patterns of production and consumption, lifestyles, and cultural conventionalities, but also national and global political framework conditions - have to be considered to understand and assess societal developments. If the integrative sustainability concept is used as normative framework for technology assessment, it has to be kept in mind that technology can only make (positive as well as negative) contributions to a sustainable development (Weaver et al., 2000). Moreover, these contributions always have to be seen against the background of other societal developments. Energy technologies as such are neither sustainable nor unsustainable but can only make more or less large contributions to sustainability - or cause problems.

First of all it has to be determined which principles of sustainability are relevant for technology assessment. The following principles can prima facie be considered relevant in the energy context: Protection of human health, securing the satisfaction of basic needs, sustainable use of renewable resources, sustainable use of non-renewable resources, sustainable use of the environment as a sink, avoidance of unacceptable technical risks, participation in societal decision-making processes, equal opportunities, internalization of external social and environmental costs and society's reflexivity. Characteristic aspects of the relation of these principles to technology will be described in the following, including the wording of the principle (for a more detailed explanation see Kopfmüller et al., 2001).

\section{Protection of human health}

Dangers and intolerable risks for human health due to anthropogenically-caused environmental impacts have to be avoided. Production, use, and disposal of technology often have impacts which might negatively affect human health both in the short or long term. On the one hand this includes accident hazards in industrial production (work accidents), but also in everyday use of technology (the large number of people injured or killed are a sustainability problem of motorized road traffic). On the other hand, there are also "creeping" technology impacts which can cause harmful medium- or long-term effects by emissions into environmental media. The history of the use of asbestos and its devastating health effects 
are a particular dramatic example from the working environment (Gee \& Greenberg, 2002). However, there are also - at least in industrialized countries - the big successes in combating diseases or the prolongation of the human life expectancy due to medical progress or sanitary supply and disposal technologies. Also food preservation technologies and the resulting improvement of nutrition are positive effects.

Securing the satisfaction of basic needs

A minimum of basic services (accommodation, nutrition, clothing, health) and the protection against central risks of life (illness, disability) have to be secured for all members of society. Technology plays an outstanding role in securing the satisfaction of basic human needs through the economic system; energy supply is also essential for this. This applies directly for the production, distribution, and operation of goods to satisfy the needs (e.g. technical infrastructure for the supply of water, energy, mobility, and information, waste and sewage disposal, building a house, household appliances). However, this is on the one hand opposed by numerous negative impacts resulting from this way of need satisfaction common in industrialized countries (which then show up against the background of other sustainability principles). On the other hand, it has to be kept in mind that a large part of the world population is still cut off from this basic satisfaction of needs secured by means of technology. For example, approx. 2 billion people do not have access to a regular energy supply. Some 1.2 billion people worldwide have no adequate drinking water supply. 2.4 billion people are not connected to a safe and hygienic wastewater disposal.

\section{Sustainable use of renewable resources}

The usage rate of renewable resources must neither exceed their replenishment rate nor endanger the efficiency and reliability of the respective ecosystem. Renewable natural resources are e.g. renewable energies (wind, water, biomass, geothermal energy, solar energy), ground water, biomaterials for industrial use (e.g. wood for building houses) and wildlife or fish stock. In the historical development of the concept of sustainability the principle on renewable resources has played a major role in the context of forestry and fishery. It contains two statements. On the one hand, it is essential that resources are extracted in a gentle way to protect the inventory. Human usage shall not consume more than can be replenished. On the other hand, it has to be ensured that the respective ecosystems are not overstrained, e.g. by emissions or serious imbalances. Here technology plays an important role in using the extracted resources as efficient as possible (e.g. energetic use of biomass) and minimizing problematic emissions.

\section{Sustainable use of non-renewable resources}

The reserves of proven non-renewable resources have to be preserved over time. The consumption of non-renewable resources like fossil energy carriers or certain materials calls for a particularly close link to technology and technological progress. The consumption of nonrenewable resources may only be called sustainable if the temporal supply of the resource does not decline in the future. This is only possible if technological progress allows for such a significant increase in efficiency (von Weizsäcker et al., 1995) of the consumption in the future that the reduction of the reserves imminent in the consumption does not have negative effects on the temporal supply of the remaining resources. So a minimum speed of technological progress is supposed. The principle of reserves directly ties in with efficiency strategies of sustainability; it can be really seen as a commitment to increase efficiency by 
technological progress and respective societal concepts of use for the consumption of nonrenewable resources. One alternative, which also depends on the crucial contributions of technological concepts, would be substituting non-renewable resources in production and use of technology with renewable ones (e.g. the reorganization of the energy supply for transport from mineral oil to electricity from regenerative sources). Regarding the material resources, the ideal of recycling management includes the idea of recycling the used materials to the largest extent and in the best quality possible; thus the available resources would hardly decline in amount and quality. However, this ideal reaches its limits, since recycling normally includes high energy consumption and material degeneration.

Sustainable use of the environment as a sink

The release of substances must not exceed the absorption capacity of the environmental media and ecosystems. Extraction of natural resources, processing of materials, energy consumption, transports, production processes, manifold forms of use of technology, operation of technical plants, and disposal processes produce an enormous amount of material emissions which are then released into the environmental media water (ground water, surface water, and oceans), air, and soil. These processes often cause serious regional problems, especially concerning the quality of air, ecosystems, biodiversity, and freshwater. However, environmental measures taken in industrialized countries led to considerable progress in this respect over the last decades. Unfortunately, this does neither apply for most developing and newly industrializing countries nor for global effects like degradation of soil used for agriculture, accumulation of persistent pollutants in polar seas, or the release of greenhouse gases. Technology plays a major role in all strategies for solving these problems. On the one hand, as an "end-of-pipe" technology it can reduce the emissions at the end of technical processes, e.g. in form of carbon capture and storage (CSS). On the other hand, and this is the innovative approach, technical processes can be designed in a way that unwanted emissions do not occur at all. This requirement usually results in a significant need for research and development which even extends to basic research.

\section{Avoidance of unacceptable technical risks}

Technical risks with potentially disastrous impacts for human beings and the environment have to be avoided. This principle is necessary since the way to handle disastrous technical risks is insufficiently described in the three "ecological management principles". These management principles refer to "failure-free normal operation" and disregard possible incidents and accidents as well as unintended "spontaneous side effects". They are rather intended for long-term and "creeping" processes like the gradual depletion of natural resources or the gradual "poisoning" of environmental compartments. The risk principle refers to three different categories of technical risks: (1) risks with comparatively high occurrence probability where the extent of the potential damage is locally or regionally limited, (2) risks with a low probability of occurrence but a high risk potential for human beings and the environment, (3) risks that are fraught with high uncertainty since neither the possibility of occurrence nor the extent of the damage can currently be sufficiently and adequately estimated. This principle is closely linked to the precautionary principle (by von Schomberg, 2005). It could be applied to the problems discussed in the context of a severe nuclear reactor accident (worst-case scenario such as recently happened at Fukushima, 
Japan), for securing the long-term safety of a final repository for highly radioactive waste, or possible risks of the release of genetically modified organisms.

\section{Conservation of nature's cultural functions}

Cultural and natural landscapes or parts of landscapes of particular characteristic and beauty have to be conserved. A concept of sustainability only geared towards the significance of resource economics of nature would ignore additional aspects of a "life-enriching significance" of nature. The normative postulate to guarantee similar possibilities of need satisfaction to future generations like the ones we enjoy today can therefore not only be restricted to the direct use of nature as supplier of raw materials and sink for harmful substances but has to include nature as subject of sensual, contemplative, spiritual, religious, and aesthetic experience. Within the energy context one has to be reminded of the final repository for radioactive waste at Yucca Mountain in the United States, where problems occurred due to the spiritual meaning of the region to the indigenous population. Also the changing landscapes due to wind farms are a problem in some regions; this is discussed not only in connection with tourism but also regarding the aesthetic values of landscapes.

\section{Participation in societal decision-making processes}

All members of society must have the opportunity to participate in societally relevant decision-making processes. Regarding technology, this principle has a substantial and a procedural aspect (see in general Joss \& Belucci, 2002). On the one hand (substantially) it affects the design of technologies which (might) be used for participation. Here the principle calls for exploiting these potentials of participation as far as possible. On the other hand (procedurally) the principle aims at the conservation, extension, and improvement of democratic forms of decision-making and conflict resolution, especially regarding those decisions which are of key importance for the future development and shaping of the (global) society; the aspect of designing future energy systems is definitely part of this. Future energy supply, far-reaching ethical questions of biomedical sciences with probably significant cultural impacts, questions of risk acceptance and acceptability in case of genetically modified food are examples for technological developments with a considerable sustainability relevance which should be according to this principle - dealt with participative methods.

\section{Equal opportunities}

All members of society must have equal opportunities regarding access to education, information, occupation, office, as well as social, political, and economic positions. The free access to these goods is seen as prerequisite for all members of society to have the same opportunities to realize their own talents and plans for life. This principle primarily relates to questions of societal organization where technology only plays a minor role. However, the availability of energy is often a crucial precondition for being able to participate in societal processes at all, e.g. for having access to information and communication technologies which need energy or mobility which is also impossible without energy. The fact that approx. 2 billion people in the world do not have access to a regular energy supply underlines the circumstance that this also considerably restricts their possibilities of participation. Furthermore, the access to information has to be mentioned as another central challenge. The call for equal opportunities regarding the access to societally relevant information includes expectations of the technical infrastructure (e.g. technical enabling of Internet access by being connected to a suited communication network), but also the requirements to the competences of the 
user to be able to handle this technical infrastructure and use it accordingly. Concerning the effects of Internet use on democracy, there were high hopes that the Internet could revive or renew democracy. The facilitated access to information and the new options for communication were expected to lead to an "empowerment", i.e. they would turn citizens who are only little informed and disenchanted with politics into active and well-informed citizens (cf. Grunwald et al., 2006). These visions turned out to be illusions, which was apart from other reasons (Grunwald et al., 2006) - also due to the fact that the realization of positive hopes concerning democracy required easy Internet access for everyone not just "in theory" but also "in reality", a precondition which has by far not been fulfilled. This does not only apply for the disparity between Internet use in industrialized and developing countries, but is also a problem of developed countries where e.g. elderly people or people from disadvantaged groups often cannot deal with this technology with its high innovation rate (both aspects together are often referred to as "digital divide").

\section{Internalization of external social and environmental costs}

Prices have to reflect the external environmental and social costs arising through the economic process. One reason for the neglect of essential ecological and social aspects in the economic process, for suboptimal allocation of resources, and the resulting sustainability deficits lies in the fact that only one part of the costs arising from the production and consumption process is considered for pricing. The so-called "external effects" or "external costs" refer to the effects of production and consumption activities which are not borne by the causer but by third parties and are a priori not subject to a regulation via market or pricing mechanisms. External effects lead to distortions of prices and the structure of goods and therefore also to discrepancies between commercial and societal costs and/or between micro and macro rationalities of the market process which contributes to the development of sustainability deficits. The call for cheap energy or cheap materials often result in not taking the "real" costs as a basis since negative impacts for the environment, health, and future generations are not implied. Exempting fuel from the tax liability is one example for the lacking internalization of such external costs.

\section{Appropriate discounting}

Discounting shall neither discriminate against today's nor future generations. Discounting procedures are used to make effects in the form of economically relevant quantities occurring at different times comparable and assessable for current decision-making processes. In doing so, cost and benefit items which result from investments and other activities in the course of the given period are discounted to their current or cash value. So the question is how much a subsequent loss or benefit is worth compared to today's losses or benefits. Answers to this question are crucial for long-term developments. Relevant examples include the determination of strategies to deal with the climate change, with highly radioactive wastes which have to be controlled for millenniums and burden future generations with costs and possible risks. The question of the appropriate discount rate cannot be decided ethically or scientifically but only politically - albeit in accordance with scientific information and ethical orientation.

Society's reflexivity

Institutional arrangements have to be developed, which make a reflection of options of societal action possible, which extend beyond the limits of particular problem areas and individual aspects of 
problems. Technology is future-oriented. It is developed in relation to aims and functions and shall realize certain technological functions and performance characteristics which are not yet achievable today. The intended aims of technology and the subsequent real impacts of its use are not always identical (Grunwald, 2009). If the technological development is finished and the respective technology is implemented or used, the relation to the future changes. Then technology no longer has only anticipated but also real impacts. The aims pursued with technology may be achieved only partially, others might be exceeded. Technologies which were expected to be a promising and profitable solution turn out to be commercially unsuccessful while functionalities which were rather developed as a "byproduct" are the big winner. Impacts of the use of certain technologies, either feared or hoped for, do not occur at all or not in the expected extent; there are side effects which nobody anticipated. When it comes to technology design for sustainability, possible nonintended impacts have to be taken into account early enough. Given the far-reaching societal impacts of technology, the instrumental sustainability principle on reflexivity calls for (a) strengthening the awareness for impacts, conducting impact research and impact reflection, and sensitizing societal subsystems (especially policy, economy, and science) for this, (b) establishing a comprehensive and multi-perspective view on the impacts instead of just focussing on specific fields of impact, and (c) providing enough resources and time for impact reflection in societal opinion-making and decision-making processes. Technology assessment as a process accompanying technology development (Grunwald, 2009) can help to achieve this.

Sustainability principles cannot be directly transferred into guidelines for technology design or even performance characteristics for technology. They do not refer to technological requirements but to aspects of society's economic behaviour where technology is just one aspect among others. If the consequences for technology are in the focus, the context has to be taken into consideration: Which are the problems relevant for sustainability in the respective field, which technological and which societal conditions apply, how are they connected, and how does the whole (and often quite complex) structure relate to the approach of the whole system of sustainability principles. So the sustainability principles have by no means a prescriptive character for technology design. A number of steps of transfer and mediation have to be done on the way from normative orientation to concrete technology design. This task cannot be in the sole responsibility of the people involved in technology development. In particular cases societal dialogues are necessary and, where appropriate, even political decisions. Exactly this situation, where the system of sustainability principles provides orientation without determining technology in detail, supports the theory that the sustainability postulate is suitable as Leitbild for technology design. However, there are - and this will be discussed in the following - sometimes considerable conceptual and methodological challenges.

\section{Methodological challenges and the learning cycle}

Technology assessment as contribution to societal technology design has three different aspects (Grunwald, 2009): Provision of knowledge by research on technology and impacts of technology, analysis of their normative implications (assessment), and societal communication in the light of upcoming processes of opinion- and decision-making (advice). The best available knowledge provided by different scientific disciplines has to be 
considered for the design of energy technology regarding sustainability aspects. Moreover, a broad, ethically enlightened societal dialogue on the goals of design, on visions of a future society, on desirability, acceptability, and reasonability of future developments, on risks, and on the distribution of opportunities and risks is necessary. Concerning TA as sustainability assessment, this intensifies the challenges already known from other fields of TA: The spectrum which has to be considered is enlarged regarding its content, the timeframe, and by the increase of criteria relevant for the assessment. In performing such assessments and especially in providing the required knowledge, some typical and serious methodical challenges have to be dealt with (Grunwald, 2010):

- Embeddedness of technology: Technology as such is neither sustainable nor unsustainable. The contributions of technology to sustainability are co-determined by technology inherent and social or institutional elements; the ways technologies are used and embedded into society exert a strong influence (Weaver et al., 2000). Assessments have to take into consideration technological and societal processes, structures, values, customs, etc. that might be affected by the way of technology embeddedness into society.

- The life cycle approach and the prediction problem: Anticipatory sustainability assessments have to cover the entire life cycle of e.g. technologies or products, including resource mining, transport and treatment processes, the societal use processes, the impacts for both the natural environment and society, and finally the disposal phase. In sustainability assessments "prospective life cycle analyses" are needed, taking properly into account future consumer and production patterns (Brown et al., 2000), lifestyles, markets, or political and economic framework conditions - in order to provide suitable life-cycle analyses based knowledge for sustainability decisions (Schepelmann et al., 2009).

- The completeness issue and the incompleteness problem: Due to the broadness and complexity of sustainable development and its normative character, it is impossible for philosophical, economic, and pragmatic reasons to gain a definite complete picture in investigating the sustainability performance of certain subjects. Relevant sustainability aspects might be simply overseen or wrongly deemed of low relevance. Thus, decisions have to be made on the relevance or irrelevance of particular issues and on the boundaries of the systems considered.

- The integration issue and the incommensurability problem: Broadness and complexity of sustainable development also lead to another methodological issue: the heterogeneity of the various dimensions and indicators means that no common measure of sustainability can be applied to all subjects of investigation as a whole. Methodically, it is not satisfactory to measure for instance $\mathrm{CO} 2$ emissions, numbers of people affected by longterm unemployment, development co-operation activities, or the engagement in civil society organizations according to the same unique scale. The various sustainability dimensions and indicators cannot be integrated into one single measure like a "sustainability index" without incurring severe methodological problems. As the sustainability imperative is integrative by nature, any attempt to integrate data or assess results from heterogeneous aspects of "overall" sustainability demonstrates normative dimensions which strongly limit the use of common decision-analysis tools. Rather, discursive tools must be used, and political decisions made.

All these issues and challenges result in the necessity to deal with high uncertainties in approaching sustainable development (Grunwald 2004; 2008) and require an increasingly 
reflexive type of governance (Voss et al., 2006). The uncertainty and incompleteness of knowledge and the provisionality of evaluations make a complete implementation of sustainability in the sense of a detailed planning in the direction of sustainability impossible. The respective current state of the art in knowledge production plays an unfathomable role by the elaboration of sustainability strategies and assessments of current developments. It becomes obvious with all clarity that a policy of sustainability has to be carried out under conditions of uncertain knowledge and of provisional assessments. A policy of sustainability is therefore confronted with the limits of the availability of knowledge. It is ex ante not stringently decidable, whether and to what extent a political measure, a technological innovation, or a new institutional arrangement will, in actual application, "really" contribute to sustainability. Every sustainability policy has to face this situation and become - in a certain sense - "experimental" (Grunwald 2004). This situation also applies to the development of technology with regard to the requirements of sustainable development and has the result that the classical procedure, in which scientific knowledge is simply implemented or "applied", is not practicable in sustainability policy. The traditional approach, the production of knowledge through research and the application of this knowledge by politics, misses the problematic point just mentioned. Instead, knowledge and action intertwine: the road leads not only from knowledge to action (orienting approach), but also from action to knowledge (experimental approach). Precisely this situation, in combination with the impossibility of a detailed planning in the direction of sustainability, suggests understanding the relationship between science and politics in regard to implementation strategies as a process of learning (see Fig. 2).

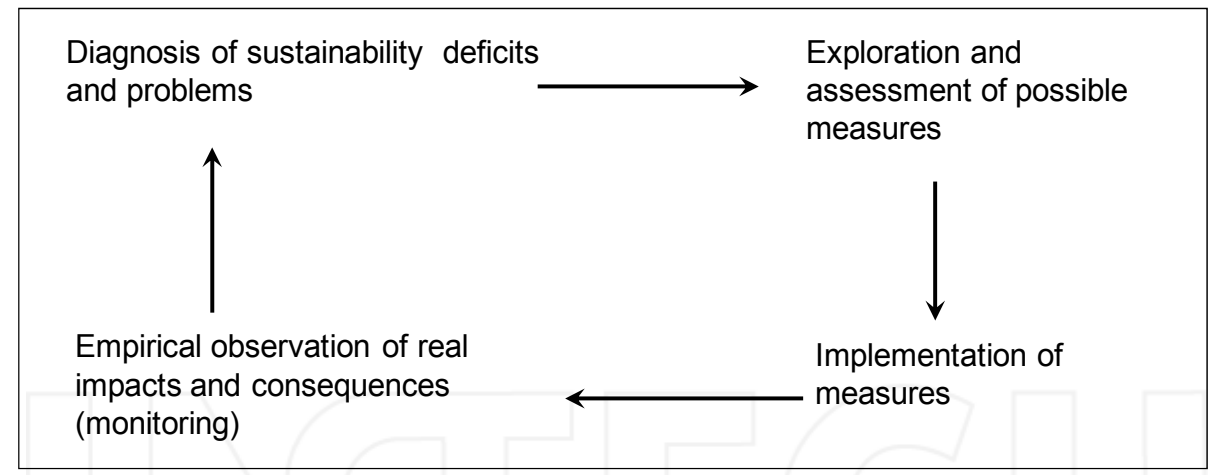

Fig. 2. Development towards more sustainability as a feedback loop involving, measures, empirical measurement and reflection. The integrative concept of sustainable development can be used for orientating diagnoses and assessments with respect to their normative substance.

For a purposive sustainability policy, it is decisive that, in this experimental situation, the inadequacy and incompleteness of knowledge doesn't paralyze or hinder action, but that, in the interpretation and implementation of practical measures, a maximum range of opportunities for learning in these "experiments" is seized. Contributions of scientific research to these learning processes consist, to put it allegorically and remain in the metaphor of the experiment, in first ensuring as good a preparation of the experiment as possible (by analyses of the situation, by causal analyses, by modelling and simulation of 
proposed measures, etc.), in supervising the careful execution of the experiment, and then in observing the results of the process, in comparing them with the goals pursued, and, if necessary, investigating the reasons for deviations.

\section{Conclusions}

The integrative approach to understand sustainability per definition without hastily reducing it to merely ecological aspects has proven the richness of the spectrum of aspects of sustainability. Of course criteria of resource economics and ecology are of special importance. But also questions of participation and equal opportunities, the way to deal with technical risks and aesthetic values of landscapes, the shaping of reflexive societal decision processes and the modelling of economic framework conditions as well as aspects of human health play crucial roles. Compared with this result it has to be noted that the sustainability debate on technologies in industrial countries is often narrowed to ecological issues, at the utmost supplemented by aspects of economic development or social peace. In contrast, it has to be pointed out: the sustainability of technologies has to be measured against a much larger spectrum of principles, criteria, and indicators than often assumed.

However, this spectrum aggravates the well-known problems of prospective sustainability assessment (Sec. 5). Especially with regard to unavoidable conflicts of objective between the different criteria of sustainability and the incommensurability of many criteria the need for a methodologically secured approach of sustainability assessment is obvious. Classical instruments like life-cycle assessment or simulations are required, but by no means sufficient. On the one hand, they have to be developed further to meet the range of sustainability criteria. Approaches like consequential LCA or social LCA veer towards this, but are of course just starting off. On the other hand, qualitative procedures of deliberation for "soft" criteria of sustainability and for the consideration of conflicts of objectives are necessary. The concept introduced in this paper does not solve these methodological problems; but nevertheless it provides a well-founded conceptual framework for the further development of these methods of assessment on a transparent basis.

Sustainability assessments of technological options, technology impacts, or innovation potentials therefore include considerable and ineliminable uncertainties. Especially assessments are made under uncertainty. This applies on the one hand for assessment criteria which are themselves subject to change over time (thinking, e.g., of the emergence of ecological awareness in the 1970s and its consequences for assessment processes). Assessments are also made relatively to the state of knowledge and are therefore dependent on uncertainty, incompleteness, and preliminarity of this knowledge. Hence the problem of knowledge (see above) has immediate effects on the assessment question. The assessment of asbestos for example changed abruptly when carcinogenic effects were discovered; in the same way the assessment of chlorofluorocarbons changed after the discovery of the mechanism which caused the ozone hole. The consequence is that design supported by TA as sustainability assessment of technology cannot be understood as a planning towards a determined goal but as a permanent process considering societal dialogues and learning processes.

The knowledge question (Grunwald, 2004) and the assessment question make a final sustainability assessment of technology impossible. The question whether sustainability will 
be achieved can only be answered in connection with the use and the embedment of technology into society. Technology can contribute more or less to a sustainable economic behaviour but cannot decide on sustainability alone. Sustainability assessments and the resulting decisions depend on the context, are preliminary, and open to further development as a result of societal learning processes: steps in a co-evolution of society and technology on a "sustainable" way into the future (Grunwald, 2008).

It is about using the manifold possibilities to understand technology design under sustainability aspects as a permanent learning process: as a societal process where design objectives and options for realization are being discussed, which is influenced by scientific knowledge and ethical orientations, where the concept of a "sustainable" technology is developed step by step. In this way, technology assessment is a medium of learning, where technology development, the development of the respective societal framework conditions, and the use of technology are critically accompanied as well as analyzed and assessed under sustainability aspects.

\section{References}

Bechmann, G., Decker, M., Fiedeler, U., Krings, B. (2007). TA in a complex world. International Journal of Foresight and Innovation Policy 4, p. 4-21

Bijker, W. E., Hughes, T.P., Pinch, T. J. (eds.) (1987). The Social Construction of Technological Systems.. Cambridge (Mass.)

Bijker, W., Law J. (eds.) (1994). Shaping Technology/Building Society. Cambridge (Mass.)

Brandl, V., Jörissen, J., Kopfmüller, J., Paetau, M. (2002). Das integrative Konzept nachhaltiger Entwicklung. In: A. Grunwald et al.. Forschungswerkstatt Nachhaltigkeit. Berlin, pp. 73-102

Brown, N., Rappert, B., Webster, A. (eds.) (2000). Contested Futures. A sociology of prospective techno-science. Burlington/ Ashgate, 2000

Brown-Weiss, E. (1989). In Fairness to Future Generations. International Law, Common Patrimony and Intergenerational Equity. New York

Daly, H. (1987): The Economic Growth Debate: What Some Economists Have Learned But Many Have Not. In: Journal of Environmental Economics and Management, Vol. 14, S. 323-336

Daly, H. (1999): Wirtschaft jenseits von Wachstum. Die Volkswirtschaftslehre nachhaltiger Entwicklung. Salzburg

Daly, H. E. (1994): Operationalizing Sustainable Development by Investing in Natural Capital. In: Jansson, A.; Hammer, M.; Folke, C.; Costanza, R. (Eds.): Investing in Natural Capital. The Ecological Economics Approach to Sustainability. Washington D.C., S. 22-37

Decker, M., Ladikas, M. (eds.) (2004). Bridges between Science, Society and Policy. Technology Assessment - Methods and Impacts. Berlin

Fleischer, T., Grunwald, A. (2002). Technikgestaltung für mehr Nachhaltigkeit Anforderungen an die Technikfolgenabschätzung. In: Grunwald, A. (ed.): Technikgestaltung für eine nachhaltige Entwicklung. Von der Konzeption zur Umsetzung. Berlin, p. 95-146

Fleischer, T., Grunwald, A. (2008). Making nanotechnology developments sustainable. A role for technology assessment? Journal of Cleaner Production 16(2008), p. 889-898 
Gee, D., Greenberg, M. (2002). Asbestos: from 'magic' to malevolent mineral. In: Harremoes, P., Gee, D., MacGarvin, M., Stirling, A., Keys, J., Wynne, B., Guedes Vaz, S. (Hg.): The Precautionary Principle in the 20 $0^{\text {th }}$ century. Late Lessons from Early Warnings. London, p. 49-63

Grunwald, A. (2004). Strategic knowledge for sustainable development: the need for reflexivity and learning at the interface between science and society. International Journal of Foresight and Innovation Policy 1(2004)1/2, pp. 150-167

Grunwald, A. (2005). Conflicts and Conflict-solving as Chances to Make the Concept of Sustainable Development Work. In: P. A. Wilderer, E. D. Schroeder, H. Kopp (eds.): Global Sustainability. The Impact of Local Cultures. A New Perspective for Science and Engineering, Economics and Politics. Weinheim: Wiley-VCH, p. 107-122

Grunwald, A. (2007). Converging Technologies: visions, increased contingencies of the conditio humana, and search for orientation. Futures39, p. 380-392

Grunwald, A. (2008). Working Towards Sustainable Development in the Face of Uncertainty and Incomplete Knowledge. Journal of Environmental Policy \& Planning Volume 9, Issue 3, pp. 245-262

Grunwald, A. (2009). Technology Assessment: Concepts and Methods. In: A. Meijers (ed.): Philosophy of Technology and Engineering Sciences. Volume 9. Amsterdam: North Holland 2009, p. 1103-1146

Grunwald, A. (2010). Technikfolgenabschätzung. Eine Einführung. Berlin, second edition

Grunwald, A., Banse, G., Coenen, C., Hennen, L. (2006). Netzöffentlichkeit und digitale Demokratie. Tendenzen politischer Kommunikation im Internet. Berlin

Grunwald, A.; Kopfmüller, J. (2006). Nachhaltigkeit. Eine Einführung. Frankfurt a. Main

JCP - Journal of Cleaner Production (2008). Sustainable Nanotechnology Development. Special Issue. Journal of Cleaner Production 16

Joss, S.; Bellucci, S. (2002). Participatory Technology Assessment in Europe: Introducing the EUROPTA Research Project. In: Joss, S.; Bellucci, S. (Eds.): Participatory Technology Assessment. European Perspectives. Center for the Study of Technology, Westminster, pp. 3-14

Kemp, R, Shot J \& Hoogma, R (1998). Regime Shifts to Sustainability Through Processes of Niche Formation: The Approach of Strategic Niche Management. In: Technology Analysis \& Strategic Management, vol.10, pp.175-195.

Kopfmüller, J. (ed.) (2006). Ein Konzept auf dem Prüfstand. Das integrative Nachhaltigkeitskonzept in der Forschungspraxis. Berlin

Kopfmüller, J., Brandl, V., Jörissen, J., Paetau, M., Banse, G., Coenen, R., Grunwald, A. (2001). Nachhaltige Entwicklung integrativ betrachtet. Konstitutive Elemente, Regeln, Indikatoren. Berlin

Paschen, H., Petermann, Th. (1992). Technikfolgenabschätzung - ein strategisches Rahmenkonzept für die Analyse und Bewertung von Technikfolgen. In: Petermann 1992, S. 19-42

RHM (2011): How sustainable is Santiago de Chile? Synthesis report of the Risk Habitat Megacity research initiative. Leipzig

Rip, A., Misa, T., Schot, J. (eds.) (1995). Managing Technology in Society. London

Schepelmann, P., M. Ritthoff, H. Jeswani, A. Azapagic, K. Suomalainen (2009). Options for deepening and broadening LCA. CALCAS - Co-ordination Action for innovation in Life-Cycle Analysis for Sustainability. Brüssel et al. 
Sen, A. (1987): On Ethics and Economics. Oxford

Sen, A. (1993): Capability and Well-Being. In: Nussbaum, M.; Sen, A. (eds.): The Quality of Life. Oxford, S. 30-53

von Schomberg, R. (2002). The objective of Sustainable Development: Are we coming closer? EU Foresight Working Papers Series 1, Brussels

von Schomberg, R. (2005). The Precautionary Principle and its normative challenges. In: E. Fisher, J. Jones, R. von Schomberg (Hg.): The precautionary principle and public policy decision making, Cheltenham, UK, S. 161-175

von Weizsäcker, E.U., Lovins, A.B., Lovins, L.H. (1995). Faktor vier. Doppelter Wohlstand halbierter Naturverbrauch. München

Voss, J.-P., Bauknecht, D. \& Kemp, R. (2006, eds.). Reflexive Governance for Sustainable Development, Cheltenham

WCED - World Commission on Environment and Development (1987). Our common future, Oxford

Weaver, P., Jansen, L., van Grootveld, G., van Spiegel, E. \& Vergragt, P. (2000). Sustainable Technology Development, Sheffield
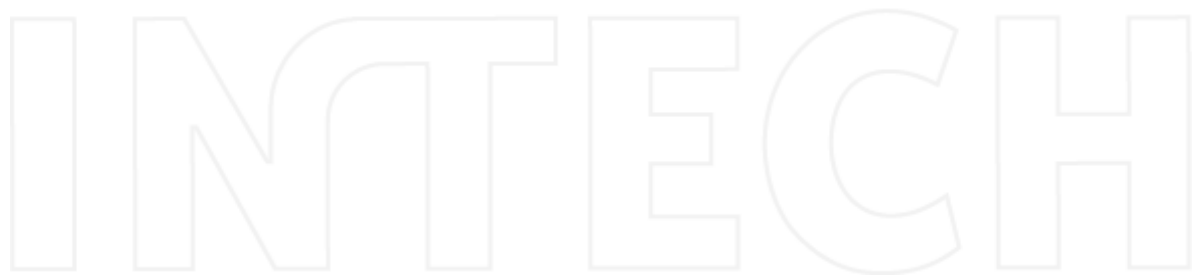


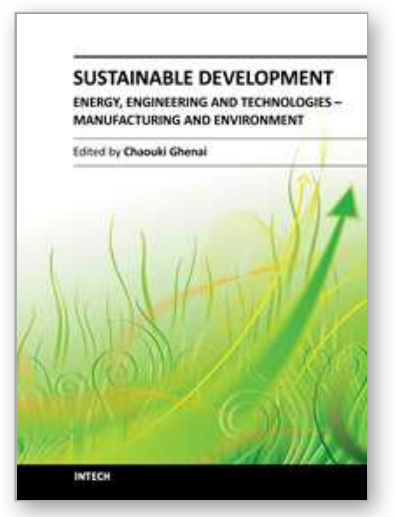

\author{
Sustainable Development - Energy, Engineering and Technologies \\ - Manufacturing and Environment \\ Edited by Prof. Chaouki Ghenai
}

ISBN 978-953-51-0165-9

Hard cover, 264 pages

Publisher InTech

Published online 29, February, 2012

Published in print edition February, 2012

The technological advancement of our civilization has created a consumer society expanding faster than the planet's resources allow, with our resource and energy needs rising exponentially in the past century. Securing the future of the human race will require an improved understanding of the environment as well as of technological solutions, mindsets and behaviors in line with modes of development that the ecosphere of our planet can support. Some experts see the only solution in a global deflation of the currently unsustainable exploitation of resources. However, sustainable development offers an approach that would be practical to fuse with the managerial strategies and assessment tools for policy and decision makers at the regional planning level. Environmentalists, architects, engineers, policy makers and economists will have to work together in order to ensure that planning and development can meet our society's present needs without compromising the security of future generations.

\title{
How to reference
}

In order to correctly reference this scholarly work, feel free to copy and paste the following:

Armin Grunwald (2012). Sustainability Assessment of Technologies - An Integrative Approach, Sustainable Development - Energy, Engineering and Technologies - Manufacturing and Environment, Prof. Chaouki Ghenai (Ed.), ISBN: 978-953-51-0165-9, InTech, Available from:

http://www.intechopen.com/books/sustainable-development-energy-engineering-and-technologiesmanufacturing-and-environment/shaping-technologies-for-sustainable-development-an-integrative-approachto-sustainability-assessmen

\section{INTECH}

open science | open minds

\section{InTech Europe}

University Campus STeP Ri

Slavka Krautzeka 83/A

51000 Rijeka, Croatia

Phone: +385 (51) 770447

Fax: +385 (51) 686166

www.intechopen.com

\section{InTech China}

Unit 405, Office Block, Hotel Equatorial Shanghai

No.65, Yan An Road (West), Shanghai, 200040, China 中国上海市延安西路65号上海国际贵都大饭店办公楼405单元

Phone: +86-21-62489820

Fax: $+86-21-62489821$ 